\begin{abstract}
Natalia Kravchuk,
Doctor of Economics, Assistant Professor, Head of the Department of International Law, International Relations and Diplomacy of the Ternopil National Economic University
\end{abstract}

\section{Yaryna Zhukorska,}

PhD in Law, Assistant Professor of the

Department of International Law,

International Relations and Diplomacy of the

Ternopil National Economic University

\section{Anastasiya Lutsyshyn,}

NHL Stenden University of Applied Science

Leeuwarden, the Netherlands

\title{
LEGAL REGULATION OF INFORMATION ACTIVITY IN THE INTERNET
}

Обгрунтовано особливості модифікації правового регулювання інформаційного контенту в глобальній мережі інтернет, у тому числі щзоо інформаційної діяльності компаній, а також щодо захисту приватних прав інтернет-користувачів, регламентування збору й поширення їхніх персональних даних. Розкрито сутність понять «інтернет-право» та «кібер-право», доведено об'єктивну необхідність їхньої гнучкості та адаптивності до змін в умовах ичифрового суспільства. Агрументовано, щзо інтернет як глобальна мережа інформаційного простору базується на свободі слова, проте потребує уніфікованих правил і правового регламентування ичирового контенту.

Ключові слова: ичифрове суспільство, інформаційний простір, правове регулювання інформаційного контенту, інтернет-право, кібер-право.

Introduction. The Internet - a tool people use daily thought in most cases do not know how it actually works and what the rules of the game are. The Internet came across fairly not that long time ago (29 y.o.) as a disruptive innovation and therefore caused the big changes to industries all over the planet and all across the markets. Companies and daily Internet users needed not only to figure out how the new platform works, what the possibilities and limitations are, but also to learn how to use it legally in the new Digital Era. Philip Kotler in his book «Marketing 4.0» (2017) states next: «... the technologies we are seeing today are not new. But they have been converging in recent years, and the collective impact of the convergence has greatly affected marketing practices around the world. New trends are emerging from this: the «sharing» economy, the «now» economy, omnichannel integration, content marketing, social CRM, and many other things» (Kotler, Kartajaya, \& Seitaiwan, 2017). It is already possible to say «looking on the past experience» when talking about the Internet since the changes are so huge and rapid that the Internet 10 years ago and now are almost two different things. Today, the Internet can be seen as a land on its own, and therefore the rules and regulations are the essential elements for the Internet to exist.

«Internet law» or as it is also called «cyberlaw», basically is «legal principles and legislation govern the use of the internet in all its forms» (Up Counsel, 2018). From the given definition it is clear that the concept of cyberlaw is very vague. It can be explained by the fact that while in the offline world there are «areas of the law» (e.g. corporate law, civil and political rights, criminal law, etc.) in the online world, Internet law cannot be identified as one solid and stable field of practice. It (cyberlaw) incorporates and applies principles from several traditional fields (Up Counsel, 2018). Such a difference in the structure of law formation between the offline and online world can be explained by two main struggles, namely the complexity of the Internet and global interface of the Internet. Explaining these two in a more detailed way, the breadth and complexity of the internet requires the cyberlaw to be flexible enough in order to cover countless real and theoretical possibilities. Moreover, because the Internet is a global interface, it makes no sense for every single country>s government create a separate set of rules and regulations, instead, the Internet should be seen as a land all its own, independent of national policy. However, there is no secret that it will be extremely hard for all the countries to agree on one set of rules and regulations that abide by internationally due to the cultural differences (Up Counsel, 2018). Therefore, there are no wonders that many people today do believe that the Internet is not actually «regulable» at all. Such state of reality is not only uncertain but also dangerous, because without the proper law all «Internet criminals» are unpunishable. 
General Objective. The objective of this paper is to explain the importance of creating a set of rules and regulations that will be applicable to online activity worldwide.

Main Question. Who should regulate online activity, the law or Internet intermediaries?

\section{Internet Law in the Music Industry}

Mark Avsec in 2016 during his speech for TEDx held in Cleveland State University gave a great example of technology and law coexistence. He made an example about the music industry when with the development of the Internet the file share has caused a big drop in music sales. Unlike with such innovation as a CD which was a great opportunity for music companies to increase their revenues by selling exactly same products but in a different format, the Internet was a more complex innovation dealing with which was not possible without new laws and regulations.

In the very beginning, the new mp3 conversion available online was unprotected and therefore could be shared, downloaded or streamed for free without any real threat. Music labels and the publishers tried to figure out how to fight back, the answer was - the law. Even though, file sharing music without permission was illegal people were still doing that. This made labels sue almost everyone, thinking that in such a way they are enforcing the law while in reality, they were alienating the market. Therefore, the conclusion can be done, labels were fighting not with the problem - «illegal file sharing» but with the technology itself. This, in turn, is a great example of the statement «Technology Leads. The Law Follows.» Since if there would be even the smallest possibility to have it the way around, music labels would have sued file-sharing out of existence. Therefore, instead, they needed to leverage the change in order to see already existed opportunity. That was what Steve Jobs and Daniel Ek did with their iTunes and Spotify respectively. From the perspective of the law, in February 2015 the Copyright Office issued a report «Copyright and the Music Marketplace», where they are recommending comprehensive reforms to the exciting music licensing structure (TEDx C. S., 2016).

Today, for instance, the rules and regulation of the music industry need to cover so many aspects and protect artists and companies from possible threats that the system starts to be very vague and confusing. For example, there are minimum six types of music license among which synchronization license (when music is paired with some form of visual media), master license (as additional license to synchronization one but applies to pre-recorded version only) and public performance license (when music is played in stores, jukeboxes, or any other form of public performance) (Musicbed, 2018).

As it mentioned above, Spotify as a company figured out how to perform within Digital Era legally. In a recent report by Michelle Castillo for CNBC it was reviled that «Spotify said it paid $\$ 9.76$ billion in royalties to artists, music labels and publishers since it launched in 2006» and the company needs to use two types of licensing simultaneously, namely public performance rights and mechanical rights because of the fact that they are a streaming platform (Castillo, 2018). The complexity of the process of buying music has a negative effect on the company from the perspective of finding investors. At the same time, the company became the largest streaming music service with 71 million paying subscribers and 159 million monthly active listeners as of December 2017. On a daily basis, they need to solve legal issues with song owners, the three big record labels (Universal Music Group, Sony Music Entertainment Group, and Warner Music Group) and Music and Entertainment Rights Licensing Independent Network (Merlin) for digital recordings from independent labels. Even with the years of experience and the big team of professionals Spotify still gets lawsuits as for example recent one with Wixen Music Publishing that claimed Spotify was using thousands of their songs illegally that worth $\$ 1.6$ billion (Castillo, 2018). This in turn, perfectly illustrates how complex the problem is and how hard it is for the companies to make sure they are not breaking a law while operating within the Digital Era.

\section{How Internet Law Regulates Online Privacy}

Another important aspect of the law that should be discussed is online privacy. While many people still believe they can keep their information, messages, or search history private it stopped being true a long time ago. Today whole portfolios are made based on the scope of the social media platforms we use, our searching engine data and even calls and messages. That personal information worth billions of dollars and is highly popular to be purchased by companies of a different kind. Therefore, it can be said that today our private information is our assets. This can be explained by the fact that such companies as Google or Facebook sell personal data for $\$ 200$ and \$116 respectively as of 2015 (TEDx B., 2015).

The information that is available online does not end on the information you insert or post yourself but also includes all the records about you in such institutions as university, hospital and so on as well as we need to be aware of location tracking, possibility of cameras and microphones on laptops, smartphones and even televisions to 
be hacked and recorded without us users noticing that. Governments of different countries are trying to somehow regulate that by passing new laws. For example, «White House: Consumer Privacy Bill of Rights» (Chernichaw, 2015), «Canada's opt-in rules could change marketing as we know it» (Fotta, 2015), «European Council approves EU General Data Protection Regulation» (Evans, 2015) and so on. However, our personal information is so desirable that companies try to think how to get it in a legal way, by for instance asking users to click the «agree» button under the so-called «agreements». Those in turn, pop up on our screens as small text which in most cases we even do not read through while in reality, they consist of 20,745 words (iTunes agreement for users) that might contain such bullet points which allow the company not only to access our private data but also use it for different purposes.

First, it is important to define the term «personal data». According to the European Commission «personal data - is any information that relates to an identified or identifiable living individual. Different pieces of information, which collected together can lead to the identification of a particular person, also constitute personal data. Personal data that has been de-identified, encrypted or pseudonymized but can be used to re-identify a person remains personal data and falls within the scope of the law.» (European Commission, 2018). The law in the framework of the Internet is shifting. One of the biggest changes was the enforcement in 2016 for Europe's General Data Protection Regulation (GDPR) - a set of rules for companies on management of personal data. And while the GDPR was passed to be applied only to EU citizens' data it is understandable that because of the global nature of the Internet the GDPR is affecting nearly every online service. This set of rules are based on the Privacy Shield and Data Protection Directive (passed by EU earlier). After passing the GDPR the process of obtaining personal data became way harder than before, explained by the fact that «any time a company collects personal data on an EU citizen, it will need explicit and informed consent from that person». In addition to that, the new law allows users to revoke that consent or request all the data a company has from them as a way to verify that consent (Russell, 2018). When talking about how effective it will be in a long run it should be said that it is hard to predict thought it is clear that the new law tries to regulate the data collection and ensure it is not used in a harmful way by checking what companies are collecting.

\section{How Internet Law Can Influence Freedom of Speech}

Another aspect that should be discussed is «freedom of speech». Because of the original idea of the Internet - to be able to reach and share information, there are no clear understanding on what can and what cannot be posted online. This in turn lead to the creation of hate groups, where violent hate speech are espoused. Today, more and more people believe that those (hate groups) should be controlled more strictly and even start to be banned. A complex overlap of «freedom of speech» and almost «terrorism», creates when we talk about hate groups (e.g. the neo-Nazi website The Daily Stormer). Natasha Tusikov the author of the book «Chokepoints: Global Private Regulation on the Internet» states that as for today though there are no real rules and regulations on how to distinguish what should be banned on the Internet since it overcomes the borders of the freedom of speech. Therefore, more and more companies «voluntarily» ban or remove such «ambiguous» content (e.g. child sexual abuse content, extremism and the illicit trade in counterfeit goods) (Tusikov, 2017).

However, are these «volunteers» doing the right thing? More specifically, is this a company that should decide what should and what should not be displayed or is this the law that should do this? For instance, Matthew Prince (CEO of Cloudflare) warned that the situation in which content is banned on the website because of the public pressure is actually a huge problem regarding the whole idea of freedom of speech (Tusikov, 2017). This perfectly illustrates the essential need in the set of global regulations regarding online behavior. Because as for today, Internet intermediaries have the potential to be powerful regulators on a wide variety of issues. This is explained by the fact that platforms can act swiftly and without court orders since they can censor any content or ban users under their terms-of-service agreements. In addition to that, with the constant development of the Internet itself, the use of automated tools to identify and remove «problematic» content is growing. Meaning that something can be taken down only because a certain word was found. Another problem is that because there are no clear regulations companies can use «mission-creep» when rules first enacted against child abuse or terrorism are later applied to other distinctly less-harmful issues, such as the unauthorized downloading of copyrighted content (Tusikov, 2017). Therefore, it can be said that while today such «volunteers» are doing good by censoring violent hate speech tomorrow they can start censoring other speeches that may be considered controversial by some. This, in turn, is ruining the concept of «freedom of speech» as a whole because while they (platforms) act like «good policemen», in reality, they are creating rules that have no legal background though implies worldwide enabling people to be sure that they have a possibility to share their opinion without being afraid to be seen as extremists in the eyes of the society or being banned because «their opinion does not lie under the beliefs of 
current government». This is a real threat because there is a tendency for big companies to become large and start controlling over meaning that if nothing is going to change soon enough we as the Internet users will be able to see just one side of the coin (like if we would have just one newspaper or just one news channel). Meaning that by depending on a «few giant networks», a «small number of companies will largely determine what can and cannot be online.» (Tusikov, 2017). However, here the question arises «is this really what we want?». Should it be companies like Facebook and Twitter to decide - independently, arbitrarily and secretly - what content we can access and share? Absolutely not! Instead, there is an urgent need in a clear set of rules to enable intermediaries to respond consistently, transparently and with respect for due process (Tusikov, 2017). In such a way, the control of specific crises like «fake news», terrorism and hate groups will be replaced by the control of the Internet as a whole and thus ensure the safety and transparency of the platform is used daily by millions of people that deserve to share and reach thought without fear but under the law.

Conclusion. All of these illustrates how beneficial and simultaneously harmful the Internet is. However, by realizing the complexity of the problem that might occur if not paying attention to it show us, regular daily Internet users, how essential the law is. The law was protecting our privacy, our rights and safety for years and now the system is going through the hard times. As it was explained in the literature review, music industry, for instance, suffer from the luck of structure in the Internet law. Due to the fact that the rules and regulation of the music industry need to cover a lot of aspects the system turned to be vague and confusing. This in turn, negatively influence companies that work within this market. Even huge players like Spotify have hard times solving legal issues with song owners, big record labels and Independent Networks that license digital recordings from independent labels.

Furthermore, more and more laws are passed when talking about online privacy. This is a huge area of law that need to ensure that all the data like messages, search history, personal information, the records in such institutions as university, hospital and so on as well as location tracking, etc. is not only collected but also sold to the companies of a different kind without people knowing about it. That personal information worth billions of dollars and therefore companies try to think how to get it in a «legal way». For instance, asking users to click the «agree» button under the so-called «agreements» that might contain such bullet points which allow the company not only to access our private data but also use it for different purposes. And even though as it was stated above, the GDPR was passed it applies only to EU citizens' data. Thus, it should not be forgotten that because of the global nature of the Internet the rules and regulations should be created not by each country separately but be a consensus and apply worldwide.

Finally, nevertheless the original idea of the Internet was to be a platform that promotes freedom of speech, today it becomes clear that information is censored. Because there is no clear understanding on what can and what cannot be posted online as for today there are still no real rules and regulations on how to distinguish what should be banned on the Internet since it overcomes the borders of the freedom of speech. And while some people are afraid that Internet starts to become a dangerous place with «ambiguous» content (e.g. child sexual abuse content, extremism and the illicit trade in counterfeit goods). Other believe that soon the Internet from the open platform can turn into carefully censored information base. This is explained by the fact that platforms (intermediators) can decide what can and what cannot be posted without court orders but under their own terms-of-service agreements. This illustrates that indeed, there is an urgent need in a clear set of rules to enable intermediaries to respond consistently, transparently and with respect for due process.

All in all, it is clear that Internet law is a very confusing and vague set of rules and regulations that cover multiple areas of law. Therefore, it is important to create a set of regulations that will be applied worldwide and will control online activity instead of specific crises like «fake news,» terrorism and hate groups. This will ensure that the Internet is the safe and transparent platform that is used daily by millions of people who deserve to share and reach thought without fear but under the law. It is clear that when it comes to our rights it should be a clear idea of consequences to all the acts that take place online and those should be respected globally. We, as users, should know our rights and be able to protect ourselves and our families from the harmful effects that might be caused by so far poorly regulated Internet.

\section{Bibliography}

1. Castillo, M. (2018, April 27). Spotify IPO filing reveals how insanely complicated it is to license music rights. Retrieved from CNBC: https://www.cnbc.com/2018/02/28/how-spotify-licenses-and-pays-for-music-rights.html.

2. Chernichaw, A. (2015, April 8). White House Re-Introduces Consumer Privacy Bill of Rights Act. Retrieved from White \& Case: https://www.whitecase.com/publications/article/white-house-re-introduces-consumerprivacy-bill-rights-act. 
3. European Commission. (2018). What is personal data? Retrieved from European Commission: https:// ec.europa.eu/info/law/law-topic/data-protection/reform/what-personal-data_en.

4. Evans, M. (2015, June 15). European Council approves EU General Data Protection Regulation draft; final approval may come by end of 2015. Retrieved from Data Protection Report: https://www.dataprotectionreport. com/2015/06/european-council-approves-eu-general-data-protection-regulation-draft-final-approval-maycome-by-end-of-2015/.

5. Fotta, J. (2015, April 25). Canada's opt-in rules could change marketing as we know it. Retrieved from Venture Beat: https:/venturebeat.com/2015/04/25/canadas-opt-in-rules-could-change-marketing-as-we-know-it/

6. Kotler, P., Kartajaya, H., \& Seitaiwan, I. (2017). Marketing 4.0. New Jersey: John Wiley \& Sons, Inc.

7. Musicbed. (2018). Types of Music Licenses. Retrieved from Musicbed: https://www.musicbed.com/knowledgebase/types-of-music-licenses/28.

8. Russell, B. (2018, May 25). Everything you need to know about GDPR 66. Retrieved from The Verge: https:// www.theverge.com/2018/3/28/17172548/gdpr-compliance-requirements-privacy-notice.

9. TEDx, B. (Director). (2015). The Future of Your Personal Data - Privacy vs Monetization / Stuart Lacey / TEDxBermuda [Motion Picture].

10. TEDx, C. S. (Director). (2016). Technology Changes, The Law Follows // Mark Avsec / TEDxClevelandStateUniversity [Motion Picture].

11. Tusikov, N. (2017, August 22). Why it's a Mistake to Celebrate the Crackdown on Hate Websites. Retrieved from The Conversation: https://theconversation.com/why-its-a-mistake-to-celebrate-the-crackdown-on-hatewebsites- 82810 .

12. Up Counsel. (2018). Internet Law: Everything You Need to Know. Retrieved from Up Counsel: https://www. upcounsel.com/internet-law.

Стаття надійшла до редакції 22.10.2018. 